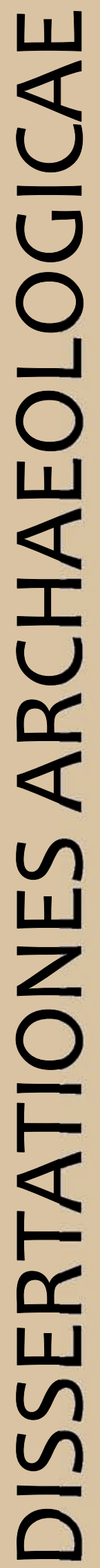

ex Instituto Archaeologico Universitatis de Rolando Eötvös nominatae

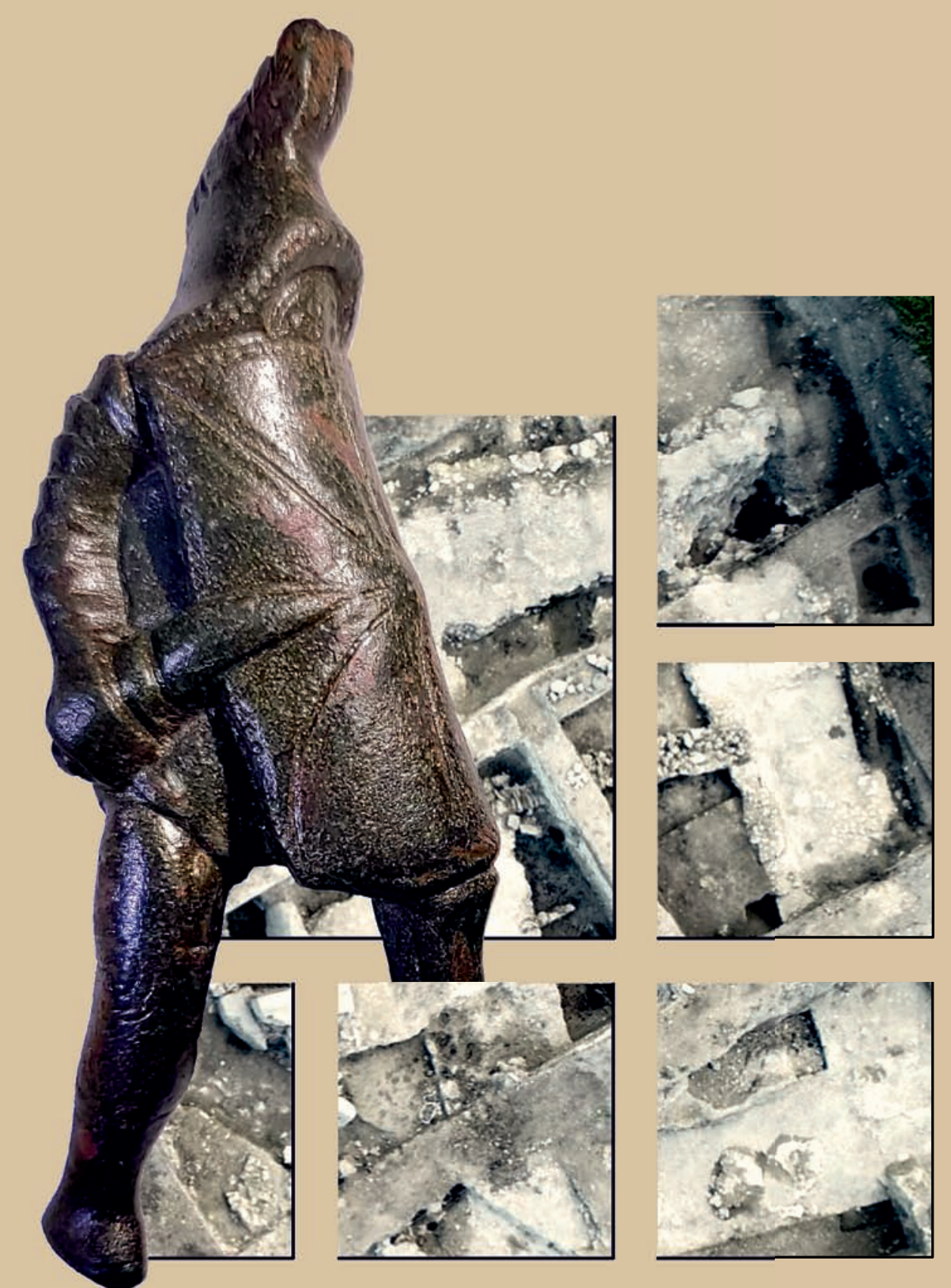

$$
\text { Ser. 3. No. 7. } 2019
$$




\section{Dissertationes Archaeologicae ex Instituto Archaeologico}

Universitatis de Rolando Eötvös nominatae Ser. 3. No. 7.

Budapest 2019 
Dissertationes Archaeologicae ex Instituto Archaeologico Universitatis de Rolando Eötvös nominatae

Ser. 3. No. 7.

Editor-in-chief:

DÁvid BARTUS

Editorial board:

LÁsZló BARTOSIEWICZ

LÁSZLÓ BORHY

ZOLTÁN CZAJLIK

IsTVÁN FELD

GÁBOR KALLA

PÁL RACZKY

MikLÓs SzABÓ

TivadAR VidA

Technical editor:

GÁBOR VÁCZI

Proofreading:

SZILVIA BARTUS-SZÖLLősI

ZsóFIA KondÉ

Aviable online at http://dissarch.elte.hu

Contact: dissarch@btk.elte.hu

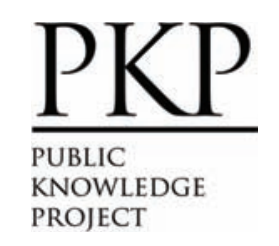

๑ ELTE Eötvös Loránd University, Institute of Archaeological Sciences

Layout and cover design: Gábor Váczi

Budapest 2019 


\section{CONTENTs}

\section{ARticles}

János Gábor TARBAY

The Casting Mould and the Wetland Find - New Data on the Late Bronze Age

Peschiera Daggers

Máté MeRvel

Late Bronze Age stamp-seals with negative impressions of seeds from Eastern Hungary

János Gábor TARBAY

Melted Swords and Broken Metal Vessels - A Late Bronze Age Assemblage

from Tatabánya-Bánhida and the Selection of Melted Bronzes

Ágnes ScHNEIDER

Multivariate Statistical Analysis of Archaeological Contexts: the case study

of the Early La Tène Cemetery of Szentlörinc, Hungary

Csilla SÁRÓ - Gábor LASSÁNYI

Bow-tie shaped fibulae from the cemetery of Budapest/Aquincum-Graphisoft Park

Dávid BARTus

Roman bronze gladiators - A new figurine of a murmillo from Brigetio

Kata DÉvAI

Re-Used Glass Fragments from Intercisa

Bence Simon

Rural Society, Agriculture and Settlement Territory in the Roman, Medieval and Modern Period Pilis Landscape

Rita RAKONCZAY

„Habaner“ Ofenkacheln auf der Burg Čabrad”

\section{FIELD REPORT}

Bence Simon - Anita Benes - Szilvia Joháczi - Ferenc BARnA

New excavation of the Roman Age settlement at Budapest dist. XVII, Péceli út (15127) site 


\section{Thesis Abstracts}

Kata SzILÁGYi

Die Silexproduktion im Kontext der Südosttransdanubischen Gruppe

der spätneolithischen Lengyel-Kultur

Norbert FARAGÓ

Complex, household-based analysis of the stone tools of Polgár-Csőszhalom

János Gábor TARBAY

Type Gyermely Hoards and Their Dating - A Supplemented Thesis Abstract

Zoltán Havas

The brick architecture of the governor's palace in Aquincum

Szabina Merva

'...circa Danubium...' from the Late Avar Age until the Early Árpádian Age-

$8^{\text {th }}-11^{\text {th }}$-Century Settlements in the Region of the Central Part of the Hungarian

Little Plain and the Danube Bend

Szabolcs Balázs NAGY

Noble Residences in the $15^{\text {th }}$ century Hungarian Kingdom - The Castles of Várpalota,

Ujlak and Kisnána in the Light of Architectural Prestige Representation

Ágnes KollátH

Tipology and Chronology of the early modern pottery in Buda 


\title{
New excavation of the Roman Age settlement at Budapest dist. XVII, Péceli út (15127) site
}

\author{
Bence Simon \\ Institute of Archaeological Sciences \\ ELTE Eötvös Loránd University \\ simon.bence@btk.elte.hu \\ SzILVIA JOHÁcZI \\ Institute of Archaeological Sciences \\ ELTE Eötvös Loránd University \\ johisziszi@gmail.com
}

\author{
Anita Benes \\ Institute of Archaeological Sciences \\ ELTE Eötvös Loránd University \\ benesanita@centrum.sk
}

FERENC BARNA

Institute of Archaeological Sciences

ELTE Eötvös Loránd University

aurelianus270@gmail.com

\begin{abstract}
In autumn 2019 the staff of the Institute of Archaeological Sciences conducted a rescue excavation in the suburbs of Budapest, on the territory of Pécel. Based on the long research history of the investigated site (Budapest dist. XVII, Péceli út) a settlement of the Imperial Period was expected. The excavation confirmed the expectations and two buildings, several ditches, an outdoor oven and numerous refuse pits were unearthed from the $3^{\text {rd }}-4^{\text {th }}$ century $A D$. The features contained many Samian ware fragments, which shed light on the Roman-Barbarian trade relations during the middle Imperial Period.
\end{abstract}

\section{The Rákos Stream and the environment of the excavation}

In Hungary the Rákos Stream with its $44 \mathrm{~km}$ length is the longest left-bank tributary stream of the Danube, the springhead of which is located at the foot of the Margita Hill in the Gödöllo Hills. The brook runs south-eastwards through the hill-country, and turns west in the area of Pécel (Fig. 1, dark blue). ${ }^{1}$ The Rákos Stream was always an important and abundant stream, with extensive marshes. In the last centuries some fishponds were established, and watermills were operating along its course. ${ }^{2}$ Although the first regulatory works of the stream can be dated to the $18^{\text {th }}$ century ${ }^{3}$ it received its current state between 1925 and 1930, when its banks were paved with concrete blocks. ${ }^{4}$

In the territory of Pécel, settlement remains of the Imperial Period were observed on both banks of the Rákos Stream (Fig. 2). Within two kilometres away from the excavation, traces of Sarmatian settlements were found to the North-East (ID: 26228) ${ }^{5}$ and at the town centre IDs: 26258, 26262). ${ }^{6}$ At the opposite bank of the Rákos Stream, on the southern slope of the Major Hill stretches the extensive Hatos-dúlő site (ID: 26222). In 2005-2006 a settlement dated

1 Oross 2003, 191; Nagy 2018, 5.

2 Oross 2003, 196-199.

3 Oross 2003, 208-210.

4 Nagy 2018, 5.

5 DinnYÉs et al. 2012, Site 19/8, 398-399.

6 DinnYÉs et al. 2012, Site 19/38, 19/42, 410-412. 
to the early and middle Imperial Period was unearthed here by B. Maráz, L. Reményi and A. Endrődi. ${ }^{7}$ The early phase of the settlement was inhabited by indigenous Celts in the $1^{\text {st }}$ and $2^{\text {nd }}$ centuries AD. During the excavation semi-subterranean houses, beehive-shaped storage pits, refuse pits, and outdoor ovens were unearthed. Besides the mostly Celtic-style pottery, Sarmatian and Roman provincial material also came to light. The later-phase part of the settlement is situated in the western part of the site, where skeletal graves, including two rich female graves were unearthed with goods dated to the $3^{\text {rd }}$ century AD. ${ }^{8}$ The finds of the settlement reflect the importance the Rákos Stream had in the trade relations between Romans and the Barbarians during the Imperial Period. ${ }^{9}$

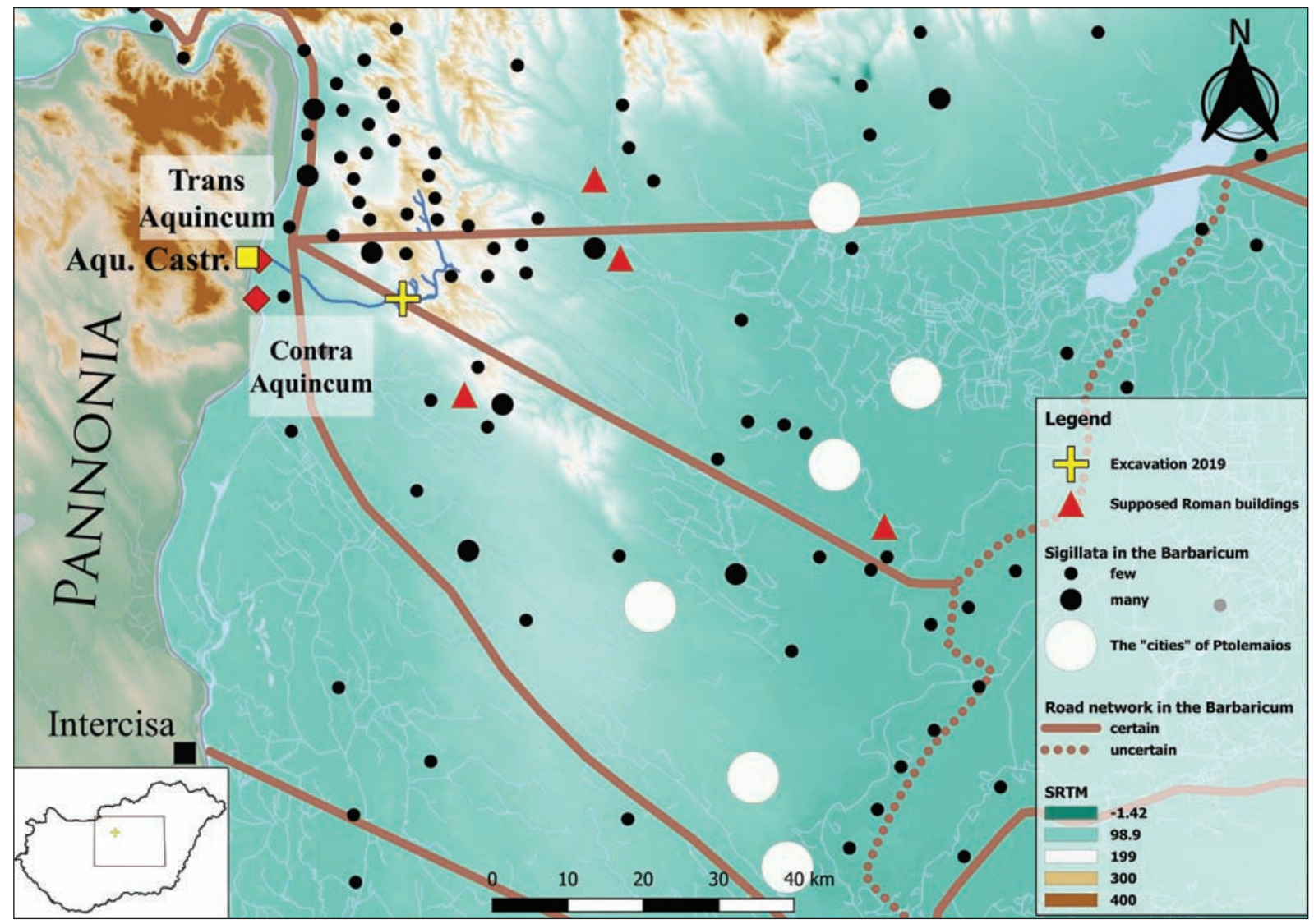

Fig. 1. Location of the excavation in the $2^{\text {nd }}-4^{\text {th }}$ c. Barbaricum (Map based on GABLER 2011, 3. tábla).

The archaeological site Budapest dist. XVII, Péceli út (ID: 15127), where the excavation was conducted, is located at the adjoining territory of Budapest (Hungary) and Pécel, on the north-facing slope of the Rákos Stream's southern bank, north of the road (Fig. 2, blue). From a geographical point of view, it is positioned at the eastern boundary of the Pest Alluvial fan micro-region, ${ }^{10}$ and it was identified through field-walking in $1975 .{ }^{11}$ The eastern boundary was probably determined out of necessity by the last house-plot of Pécel. In the past 40 years the inhabited area of the settlement expanded to the West, so the concerned

11 DinnYÉs et al. 2012, Site 19/1. 
eastern area of the site was built in. ${ }^{12}$ The natural boundary of the site to the West is the long-known ditch of a temporary rivulet heading into the Rákos Stream from the direction of the Száraz and Bartus Hill.

M. Nagy conducted the first excavation on the site between 1971 and 1987, during which a cemetery of 270 graves, and some features of the settlement came to light (Fig. 3). An area of altogether $18082.7 \mathrm{~m}^{2}$ was investigated. Both ring-ditched graves and graves arranged in rows were observed. According to the finds the cemetery was used from the second half of the $2^{\text {nd }}$ century $\mathrm{AD}$ until the turn of the $4^{\text {th }}-5^{\text {th }}$ centuries $\mathrm{AD} .{ }^{13}$

In 2005 and 2006 excavations in the eastern sector of the planned M0 highway unearthed the western part of the settlement, neighbouring the above-mentioned cemetery from the North (Fig. 3). During the rescue excavations led by A. Korom altogether an area of $28100 \mathrm{~m}^{2}$ was investigated and 2415 archaeological features were identified. Nearly all uncovered features (95\%) could be dated to the Imperial Period. The settlement was established on the hilltop above the Rákos Stream and extended in the direction of Péceli Road southwards. Altogether 28 east-west oriented semi-subterranean, rectangular (avg. $3.5 \times 3-4 \mathrm{~m}$ ) houses with rounded corners were observed. In some cases, the floor of the houses was daubed except for the earliest ones. Numerous pear-shaped outdoor ovens were unearthed with bottoms packed with shards and daubed with clay. The largest number of the features were the different kinds of pits.

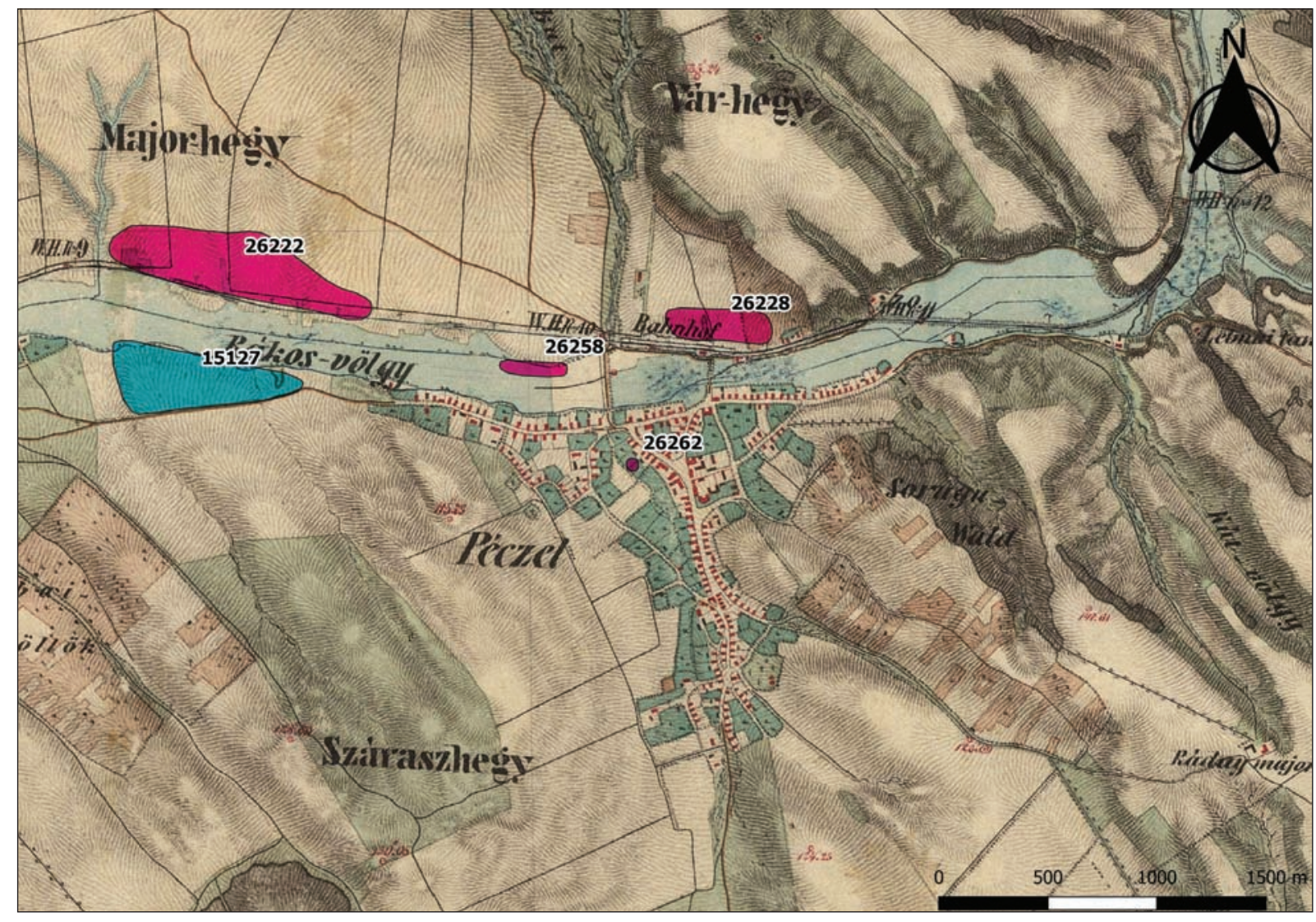

Fig. 2. Map of the $2^{\text {nd }}$ Military Survey with the identified Sarmatian settlements in the vicinity of Pécel.

12 Ковом 2006a, 181; Korom 2006b, 209.

13 Nagy 2018, 15-16, 357. 


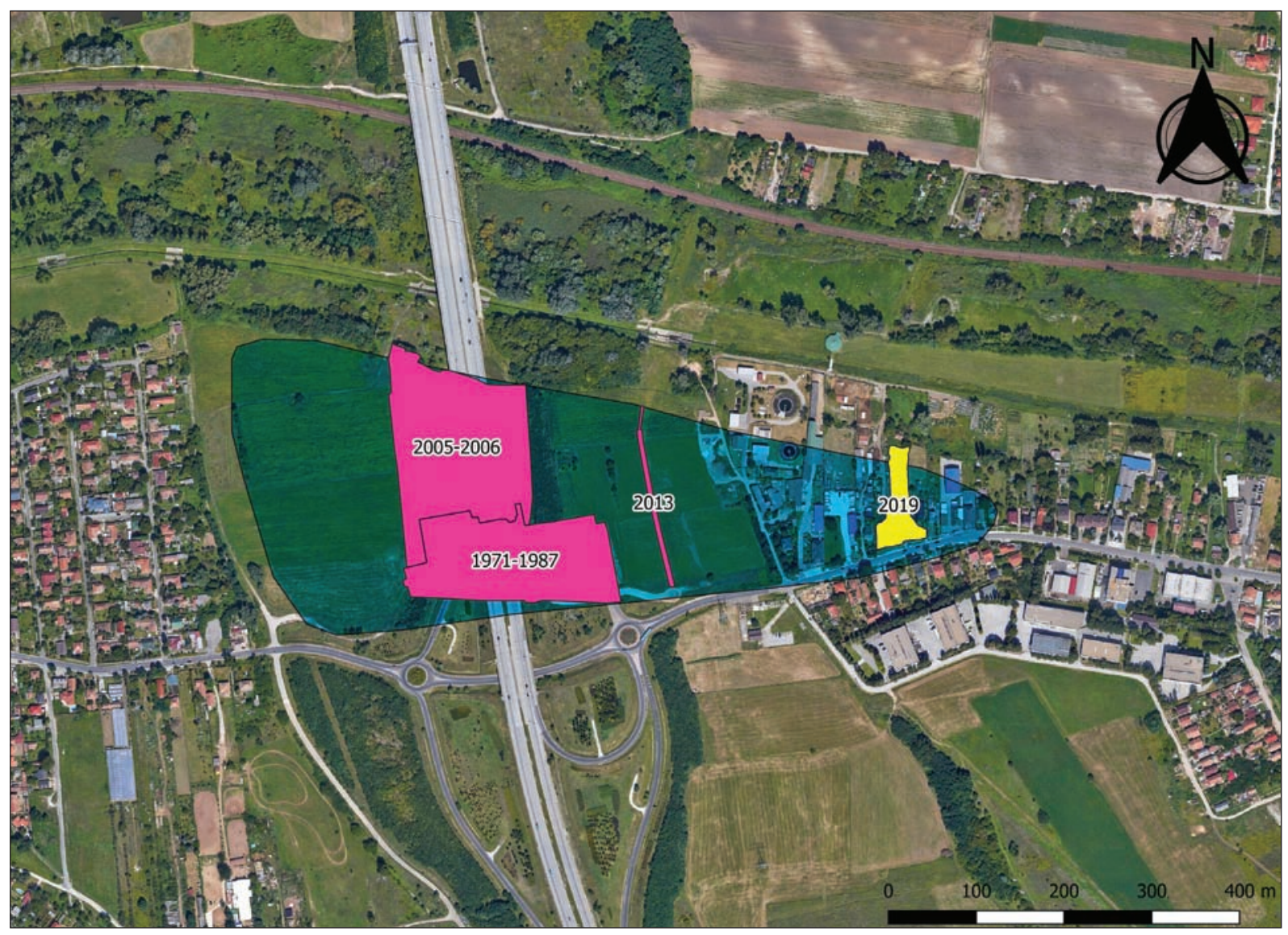

Fig. 3. Excavations at Budapest dist. XVII, Pesti út (15127) site and the location of the investigation in 2019 .

In many cases layers of ash and bones were unearthed in the refuse pits, suggesting that they had been set on fire. Sections of ditches with ' $U$ '-shaped cross-section, containing only a few finds were also observed.

The whole area of the excavation yielded shards of hand-thrown pots and grey, finely levigated pots, prepared on a fast wheel in large quantity. Numerous shards of grey, grainy wheelthrown pots from the late phase came to light too. Roman provincial ceramics i.e. Samian ware and stamped pottery occurred in larger amounts only in the early phase of the settlement, closer to the Rákos Stream. Bronze brooches, bracelets, earrings, torques and coins were also found. ${ }^{14}$ According to the archaeological finds the settlement was used from the turn of the $2^{\text {nd }}-3^{\text {rd }}$ centuries $\mathrm{AD}$ until the beginning of the $5^{\text {th }}$ century $\mathrm{AD} \cdot{ }^{15}$

In 2013 G. Szilas led a trial excavation at the site in connection with the construction of the Slovak-Hungarian Gas Interconnector (Fig. 3). Altogether $1070 \mathrm{~m}^{2}$ were investigated, and 217 archaeological features were documented. During the excavation the northern and southern boundaries of the site could be determined. While the peripheral parts of the investigated area revealed industrial features, at the central part a subterranean house and its associated storage pits were uncovered. G. Szilas dated this part of the settlement to the $3^{\text {rd }}-4^{\text {th }}$ centuries AD. ${ }^{16}$

14 Korom 2006a; Korom 2006b; Korom 2007.

15 Korom 2006a; Korom 2006b; Korom 2007.

16 SzILAs 2019. 


\section{The course of the excavation}

The staff of the Institute of Archaeological Sciences of Eötvös Loránd University ${ }^{17}$ carried out a full-surface rescue excavation in connection with the Rákos-Gödöllő railway track modernization project (401314), as subcontractor of the Ferenczy Museum Centre on commission of the Várkapitányság Zrt. The excavation was conducted in the eastern part of the Budapest dist. XVII, Péceli út 17 site, at Lrn. 02/89, 02/133, and the partially expropriated Lrn. 02/134 (Fig. 3, yellow). The excavation was carried out in two phases, between 09.27.2019-03.10.2019 and 06.11.2019 - 22.11.2019, due to the prolongation of the top-soil removal. Altogether an area of $2797 \mathrm{~m}^{2}$ was investigated and only $7 \mathrm{~m}^{2}$ turned out to be negative in terms of archaeological features. ${ }^{18}$

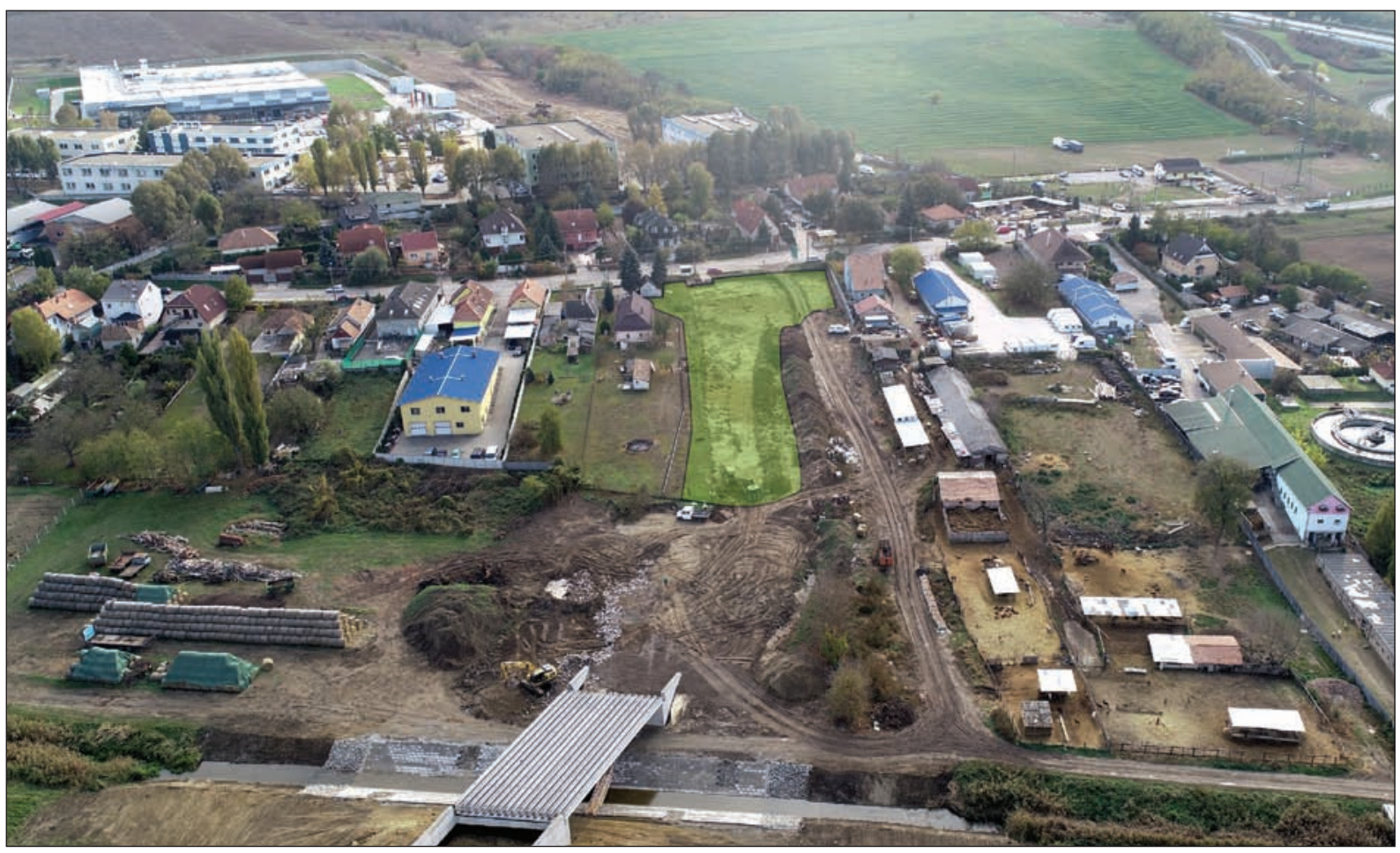

Fig. 4. Aerial photograph of the excavation (green).

The humus layers of the area designated for excavation were continuously removed between 23.09.2019 and 14.11.2019, with the participation of a JCB backhoe-loader and a Mercedes-Benz flatbed truck. At the end of September, during the first phase of the excavation, we investigated the area from the northern boundary of the archaeological site to the hilltop. In this phase the excavation was conducted on the two sides of a service road at Lrn. 02/133. It was only in November that the features under this service road and the others at the further two locations could be uncovered. The top-soil removal was conducted from the North to the hilltop in the South. On the hillside, the yellow, sandy, and red subsoil in the middle of the slope appeared at

17 The excavation was conducted by Bence Simon. Colleagues at the excavation: László Rupnik (HAS-ELTE Research Group of Interdisciplinary Archaeology), Anita Benes, Szilvia Joháczi archaeologists, Ferenc Barna, Rita Olasz, Bence Párkányi technicians, Ármin Boldizsár Ekker, Olívia Erdős, Ágoston Molnár, Mátyás Peng, Kata Szunyogh university students.

18 Calculation is based on a $10 \mathrm{~m}$ polygon radius around the recorded points. 
a depth of 25-40 cm and thickened southward towards the hilltop. The hillside had previously been cultivated as a garden, therefore the pits that we have found with rotten plant residues were considered modern features. Upon reaching the top of the hill, the layer containing organic material thickened and stretched to a depth of $110 \mathrm{~cm}$ from the surface, where the yellow, sandy subsoil appeared again. The contours of the archaeological features could be identified only 15 to $20 \mathrm{~cm}$ above or on the level of the subsoil, so it seemed necessary to remove the top-soil in this part. On 14.11.2019, when the stripping reached the front fence on Pesti Street (continuation of the Péceli Road) and left a service road through the gateway at Lrn. 02/89, the delegates of the Strabag Zrt. and Várkapitányság Zrt. decided that the area of the above-mentioned service road and the property at Lrn. 02/134 would not be stripped but preserved above the archaeological features' contact layer (Fig. 5, striped). As the areas in question were excavated at a depth of $30 \mathrm{~cm}$ during the excavation, and no contours of the archaeological features were observed, the preservation took place after the excavation.

\section{Results of the excavation}

During the full-surface rescue excavation 523 stratigraphic units were identified, representing slightly more than 250 features (Fig. 4). Besides the numerous recent and modern disturbances and pits of unknown ages, only Sarmatian features were recorded, the vast majority of which were round, oval, and beehive-shaped pits. The number of archaeological features greatly increased in the direction of the hilltop and then decreased again from the middle of the excavated area, about $15 \mathrm{~m}$ north of the Pesti Road (Fig. 5). The intensity of the features at the hilltop also suggests that the settlement extends further to the east.

On the hillside, north of the hilltop, several intersecting ditches with ' $U$ '-shaped cross-sections have been uncovered. Based on the find material, the ditches were defined as Sarmatian, but their function is still unclear. It is noteworthy that at the edge of the hilltop a $2-3 \mathrm{~m}$ wide, $80 \mathrm{~cm}$ deep and $31 \mathrm{~m}$ long ditch with a 'U'-shaped cross-section was found (Fig. 5.1). It becomes shallower and narrower to the east. Based on a Sarmatian-style T-brooch unearthed with a metal detector, it filled up around the mid- $3^{\text {rd }}$ century. ${ }^{19}$ From here the intensity of the features increased further to the south.

In this part of the excavation two rectangular buildings with rounded corners were unearthed (Fig. 5, yellow). The western one had no traces of post-holes, but the extent of the building $(4 \times 3 \mathrm{~m})$ suggests that it was probably a house. The eastern building's sides were $3 \times 3 \mathrm{~m}$ long, and its roof was supported by four irregularly placed posts. Although no fireplace was detected in the buildings, a thin reddish layer under a pile of rocks was observed in the eastern one.

A small, pear-shaped outdoor oven $(120 \times 105 \mathrm{~cm})$ was uncovered in the south-western area of the excavation (Fig. 5.2), similar to the one discovered north of the Rákos Stream at Hatos-dülo site. ${ }^{20}$ The superstructure of the oven was still recognizable, but only the plastered bottom was in good condition, and supported by medium-sized rocks (Fig. 6). The entry of the oven faced west.

20 Maráz 2009, Fig. 6. 
Some of the refuse pits on the hilltop were filled with ash and bones, which seems to be characteristic of the site. Superposition of archaeological features has been observed in relatively few cases, suggesting a shorter period of settlement. The same situation unfolds by the fact that the bottom of the features appeared at a similar level on the hilltop.

The intensity of archaeological finds also increased towards the hilltop. The richest features were located near the eastern building, and many of them contained imported Roman Samian ware shards $^{21}$ (Fig. 5, red) and fragments of grey, finely levigated pots and jugs prepared on a fast wheel. Not only the latter, but also the hand-thrown, grainy pottery type was frequent in the excavated features. In one of the pits near the eastern building, fragments of grindstones were unearthed, which suggested that the above-mentioned material is most probably the domestic waste of the nearby households. During the excavation, we screened the features twice with a metal detector, but besides modern waste and the brooch, no significant metal find was uncovered. The only exception is an antoninianus of Gordian III (AD 238), which was found on the stripped surface without any instrument.

Within the territory of the capital, Budapest dist. XVII, Péceli út is the furthermost lying Sarmatian site along the Rákos Stream and one of the best-known archaeological complexes from the Imperial Period. It is 18 kilometres far from Aquincum and 10 Roman miles away from the left-bank forts, Trans-Aquincum

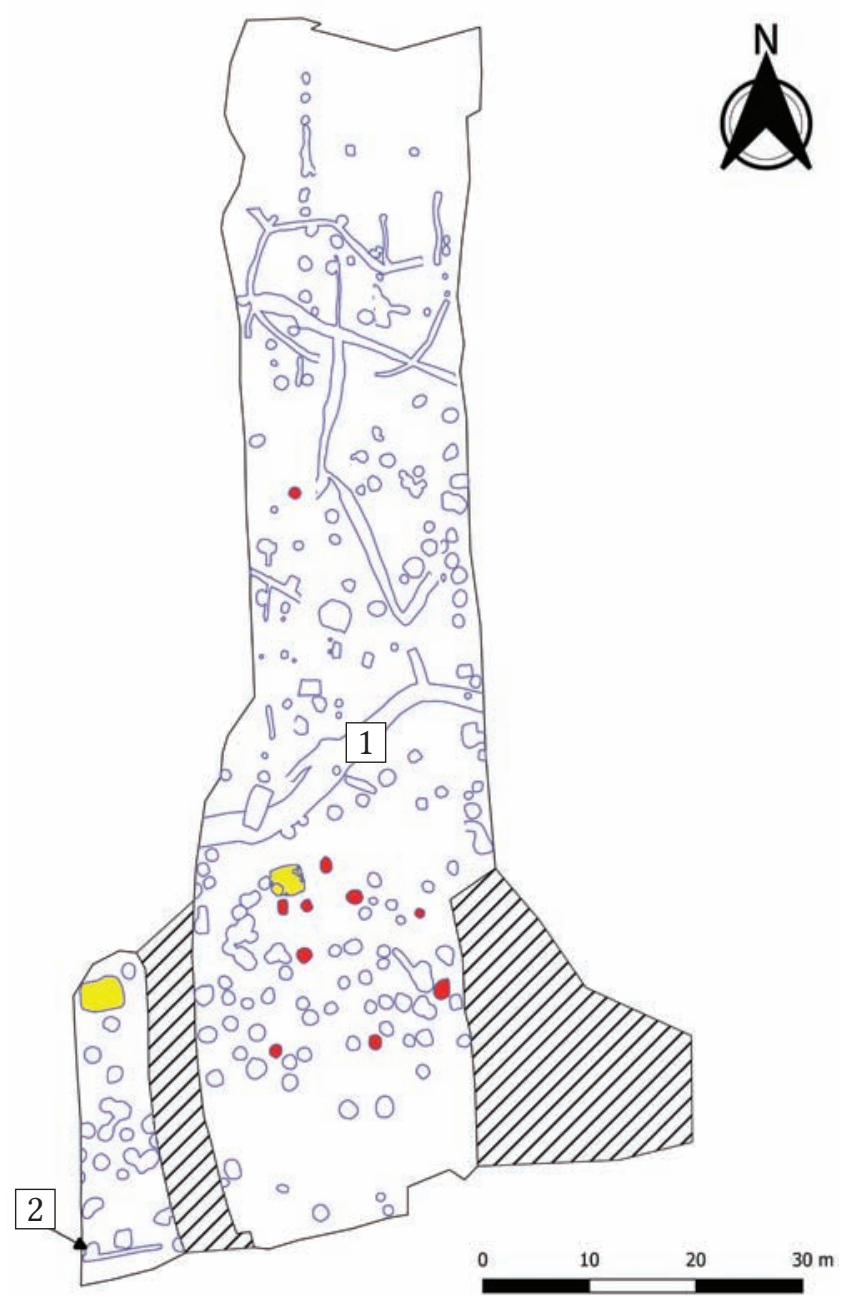

Fig. 5. Map of the excavation.

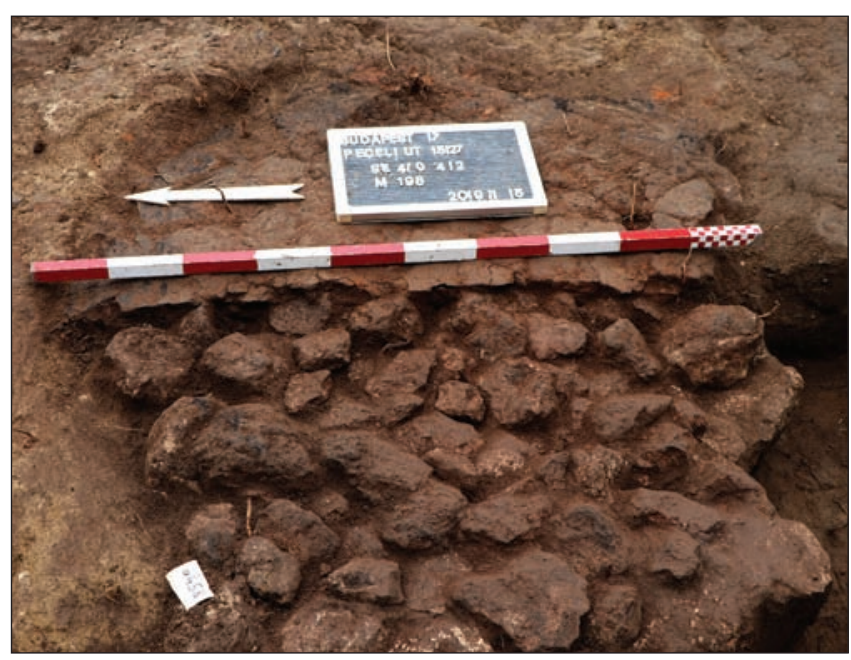

Fig. 6. Rocks supporting the outdoor oven's plastered bottom. Phase photograph.

21 The uncovered Samian ware shards could be dated from the $2^{\text {nd }}$ part of the $2^{\text {nd }}$ century to the $3^{\text {rd }}$ quarter of the $3^{\text {rd }}$ century AD. I hereby say thanks to Barbara Hajdú (BHM Aquincum Museum) for her help in the identification of the fragments. 
and Contra Aquincum (Fig. 1). According to the results of our excavation and the uncovered settlement parts to the West, the Sarmatian settlement at the site was probably established in the last decades of the $2^{\text {nd }}$ century $\mathrm{AD}$, and prospered in the $3^{\text {rd }}$ century $\mathrm{AD} .^{22}$ Based on the Samian ware finds, the coin of Gordian III and the Sarmatian-style brooch, the excavation in 2019 uncovered an early settlement phase of the site.

\section{References}

Dinnyés I. - Kővári K. - Kvassay J. - Miklós Zs. - Tettamanti S. - Torma I. 2012: Pest megye régészeti topográfiája 3. Az aszódi és a gödöllői járás. Magyarország Régészeti Topográfiája 11. Budapest.

DövÉNYi Z. (ed.) 2010: Magyarország kistájainak katasztere. Budapest.

Gabler D. 2011: Utak Pannonia és Dácia között a "Barbaricumon" át. Dolgozatok az Erdélyi Múzeum Érem és Régiségtárából. Új Sorozat III-IV, (2008-2010) 43-54.

Korom A. 2006a: Régészeti kutatások az M0 körgyưrü keleti szektorának 06. lelőhelyén (Budapest, XVII. kerület, Péceli út, Hrsz. 138598/29-38, 138598/60-73, 138598/89-95). A BTM Aquincumi Múzeum ásatásai és leletmentései a 2005. évben. Aquincumi Füzetek 12, 181-195.

Korom A. 2006b: Budapest XVII, Péceli út. In: Kisfaludy, J. (ed.): Régészeti kutatások Magyarországon 2005 (Archaeological Investigations in Hungary 2005). Budapest, 209-210.

Korom A. 2007: Budapest XVII, Péceli út. In: Kisfaludy, J. (ed.): Régészeti kutatások Magyarországon 2006 (Archaeological Investigations in Hungary 2005). Budapest, 182.

MARÁz, B. 2009: Császárkori település és temetkezések. Budapest XVII. ker., Rákoscsaba, Major-hegy dél (M0 BP02 lelöhely) (On the Outskirts of Budapest. Settlement and Burials from the Period of the Roman Empire). In: EndrődI, A. - SzILAs, G. (eds): Budapest peremén. A Budapesti Történeti Múzeum régészeti kutatásai az M0 autóut nyomvonalán /Keleti szektor/ 2004-2006. (On the outskirts of Budapest. Archaeological investigations of the Budapest History Museum in the track of highway M0 2004-2006). Budapest.

Nagy M. 2018: A Budapest XVII, Rákoscsaba, Péceli úti császárkori barbár temetô I-II. (Das barbarische Gräberfeld Budapest XVII. Bezirk, Rákoscsaba, Péceli Straße aus der jüngeren Kaiserzeit [2-4. Fahrhundert n. Chr.] I-II.) Budapest.

Oross A. 2003: A Rákos-patak területének történeti földrajzi vázlata. Forráskutatás és történelmi segédtudományok 10, 191-232.

SzIlas G. 2019: Budapest, XVII. Péceli út (KÖH 15127). In: Kvassay, J. - KreIter, A. (eds): Régészeti kutatások Magyarországon 2013 (Archaeological Investigations in Hungary 2013). Budapest, 21-22.

\section{Abbreviations}

D.C.: Dio Cassius: Rómaiké historia.

22 Based on the peace condition accepted in $175 \mathrm{AD}$, which ordered the evacuation of a 10 Roman miles-wide area (D.C. 71,15,17) and the site's actual distance from Aquincum, the date of establishment seems probable. Oross 2003, 215-232; NAGY 2018, 14. 